\title{
Tracking the South African marketing index
}

\author{
Alwyn P. du Plessis \& Christo Boshoff \\ Department of Business Management, University of Port Elizabeth, P.O. Box 1600, Port Elizabeth, 6000 Republic of South Africa
}

Received June 1997

\begin{abstract}
This study analyses marketing and marketing activities from a consumer's point-of-view. It measures consumer attitudes towards the so-called 4 Ps (product, price, promotion and retailing) and converts these scores to an overall 'attitude towards marketing' index. It also compares the results of similar studies conducted in previous years. A survey of randomly selected South African consumers reveals that the South African Marketing Index is +22.28 (in the range -200 to +200 ). suggesting reasonably favourable perceptions of marketing and marketing practices. This is the first time since the commencement of this longitudinal study that the overall marketing index has been positive. The most favourable individual index is the retailing index $(+22.91)$, followed by the price index $(+13.11)$. Both the product and the advertising indices are, however, negative $(-5.49$ and -1.33 respectively).
\end{abstract}

\begin{abstract}
In hierdie studie word bemarking en bemarkingsbedrywighede vanuit 'n verbrikersoogpunt geanaliseer. Die houdings van verbruikers ten opsigte van die sogenaamde 4 P's (produk, prys, distribusie/kleinhandel en promosie) word gemeet en omgeskakel na ' $n$ indeks van houding ten opsigte van bemarking. ' $n$ Opname onder ' $n$ ewekansige steekproef Suid-Afrikaanse verbruikers toon dat die Suid-Afrikaanse Bemarkingsindeks +22.28 is (spreiding -200 tot +200 ). By implikasie beteken dit dat verbruikers ' $n$ redelike postiewe beeld van bemarking en bemarkingspraktyke openbaar. Dit is die eerste keer sedert die aanvang van hierdie herhalende studie dat die oorkoepelende bemarkingsindeks positief is. Die kleinhandelsindeks het die grootste $(+22.91)$ waarde van die individuele indekse getoon, gevolg deur die prysindeks $(+13.11)$. Beide die advertensieen produkindeks is egter negatief ( -5.49 en -1.33 onderskeidelik).
\end{abstract}

\section{Introduction}

The philosophy of the marketing concept exhorts marketers to base all their decision-making first and foremost on consumer needs. If that is the case business firms will be market orientated. A firm that is market orientated will, it is believed, benefit in terms of, amongst other things, superior profitability (Kohli \& Jaworski, 1990). The researchers (Kohli \& Jaworski, 1990; Narver \& Slater, 1990) who have done the seminal work on market orientation agree that market orientation is a multi-dimensional construct but disagree on the nature of those dimensions, which have complicated measurement issues. A further problem is that market orientation is measured at the attitudinal level (Diamantopoulos \& Hart, 1993: 93). In other words, it measures how respondents (normally top management or marketing managers) feel about their firms. It does not measure specific actions that signify the actual implementation of the marketing concept by the firm. A further, related problem, is that it measures market orientation from an internal (company) perspective. Ideally actual customers should evaluate the market orientation of specific firms. This problem is unlikely to be solved soon, however, when one considers the definitions of market orientation. Kohli \& Jaworski (1990) refer to the need for information about customer needs, the dissemination of this information to all departments and the firm's responsiveness to this information. Narver \& Slater (1990) also refer to a customer orientation, but add a competitor orientation and interfunctional orientation. With market orientation defined in this way, how can customers assess a firm's interfunctional orientation or its ability to disseminate information about customer needs internally?

Consumers can have and do have perceptions of the marketing practices of business firms at both the micro (firm) level and at the macro level. An example of macro-level assessment is the measurement of customer satisfaction of a national level (Sweden and the United States) by Anderson \&
Fornell (1994) and Fornel, Johnson, Anderson, Cha \& Bryant (1996) respectively. Further evidence is the opinions expressed by consumers in the letter columns of newspapers and magazines. Marketing practices are often criticized. A letter writer in a New Zealand newspaper recently wrote:

'The enthusiasm for Halloween is of course fuelled by retailers. It is not surprising that they will use Halloween as yet another attempt to bewitch shoppers into unnecessary spending. These are after all the same people who put up Christmas decorations in November and who attempted to launch "Grandparents day". The spectre of crass commercialism again raises its ugly head.'

If this is a universally held view that retailers exploit consumers, then it is obvious that the principles of the marketing concept are not adhered to in practice. Inadequate implementation of the marketing concept is a view held by some academics as well. Neese (1996: 6) recently wrote: 'Unfortunately (as most faculty are aware), many practitioners do not adhere to the Marketing Concept'. Whether that is the case in South Africa was the primary objective of this study. It considers whether these rather critical views of marketing and marketing practices are representative of South African consumers by measuring consumer attitudes towards marketing. In other words, do the market orientation of South African firms reflect in the way they market their products and sevices?

The objective of this study was not to measure market orientation at the micro level. Rather it was to consider, at a macro level, whether South African business firms are perceived as being marketing orientated by measuring consumer sentiment towards marketing and marketing practices. A second objective was to compare the results of this study with two similar studies conducted in 1990 and 1993 (Boshoff \& Du Plessis, 1992; Boshoff \& Du Plessis, 1995). 


\section{Measuring consumer sentiment towards marketing}

This study attempts to assess to what extent South African business firms are considered to be consumer oriented by measuring consumer attitudes towards marketing practices and marketing firms using the 'Marketing Index' questionnaire developed by Gaski \& Etzel (1986).

In building on the initial work of Barksdale et al. (1976), Gaski \& Etzel developed a measuring instrument to gauge consumer attitudes toward marketing in general as well as the four Ps (product, price, promotion, distribution/retailing). The Marketing Index questionnaire taps consumer attitudes towards the four Ps on a five-point Likert-type scale and is then converted to an attitude score for an individual respondent. The mean attitude score per individual respondent is then converted to an index of general sentiment (the Marketing Index) and an individual index for each of the four Ps.

\section{Methodology}

The population was defined as all South African consumers. Obtaining a sampling frame to reflect the entire population was, as could be expected, almost impossible. As a result any choice of a sampling frame would suffer from some limitation. After considering a variety of options against the background of cost constraints an address list was purchased from a professional direct marketing company. The database, it is claimed, is representative of the South African population. The parameters of the sampling frame were specified as follows: a random sample, a 50\% male-female and EnglishAfrikaans split and ages above 20. Questionnaires were mailed to a random sample of 2000 South African households. Of these, 486 or $24.3 \%$ were returned. Table 1 provides an exposition of the respondent group's demographic characteristics.

In any survey, but particularly mail surveys, measurement error is a matter of concern. Non-response bias is a particularly important issue when a mail survey is used as the datacollection technique which often suffers from relatively low response rates. To assess non-response bias objectively Armstrong \& Overton (1977) suggests a time-trends approach based on the contention that non-respondents are likely to be similar to the late respondents rather than the early ones. As responses were recorded as they were received a comparison between late and early respondents could be carried out as suggested by Armstrong \& Overton (1977). Chi-square values were then calculated to assess the differences between early and late respondents. The analysis revealed that no differences existed between early and late respondents in terms of age, gender, level of education, employment status or area of residence (urban versus rural). The chi-square test did, however, suggest that the sample contain a disproportionate number of respondents with tertiary qualifications. In other words, there were slightly more tertiary qualified respondents in the sample than in the population. Although not confirmed by Armstrong \& Overton's (1977) time-trends approach, an inspection of Table 1 suggests an under-representation of those whose home language has traditionally been an African language (although some may have indicated that English is their home language). These results and a comparison of previous samples used for similar studies (Boshoff \& Du Plessis. 1992; Boshoff \& Du Plessis, 1995) suggest a representative

\begin{tabular}{|c|c|c|}
\hline \multicolumn{3}{|l|}{ Demographic variables } \\
\hline \multicolumn{3}{|l|}{ Gender: } \\
\hline Males & 247 & 50.8 \\
\hline \multirow[t]{2}{*}{ Females } & 239 & 49.2 \\
\hline & 486 & 100.0 \\
\hline \multicolumn{3}{|l|}{ Age: } \\
\hline $20-24$ & 23 & 4.7 \\
\hline $25-34$ & 91 & 18.7 \\
\hline $35-44$ & 120 & 24.7 \\
\hline $45-54$ & 110 & 22.6 \\
\hline $55-64$ & 69 & 14.2 \\
\hline \multirow[t]{2}{*}{$65+$} & 73 & 15.0 \\
\hline & 486 & 100.0 \\
\hline \multicolumn{3}{|l|}{ Level of education } \\
\hline Std 8 and lower & 38 & 7.8 \\
\hline Std 9 or equivalent & 17 & 3.5 \\
\hline Std 10 or equivalent & 147 & 30.2 \\
\hline Matric plus diploma(s) & 167 & 34.4 \\
\hline \multirow[t]{2}{*}{ Matric plus degree(s) } & 117 & 24.1 \\
\hline & 486 & 100.0 \\
\hline \multicolumn{3}{|l|}{ Home language } \\
\hline African language & 46 & 9.5 \\
\hline English & 246 & 50.6 \\
\hline \multirow[t]{2}{*}{ Afrikamns } & 194 & 39.9 \\
\hline & 486 & 100.0 \\
\hline \multicolumn{3}{|l|}{ Area of residence } \\
\hline Urban & 410 & 84.4 \\
\hline \multirow[t]{2}{*}{ Rural } & 76 & 15.6 \\
\hline & 486 & 100.0 \\
\hline
\end{tabular}

sample and it is reasonable to assume that no significant nonresponse bias was present.

\section{Data analysis}

The data analysis consisted of several elements. To evaluate the internal reliability of the Marketing Index questionnaire, Cronbach alpha coefficients were calculated. The discriminant validity of the instrument was assessed by means of an exploratory factor analysis procedure. The various indices (the four Ps and the overall index) were calculated using the formula suggested by Gaski \& Etzel (1986: 73) and used as dependent variables in a series of five regression analyses (the marketing index and the four Ps). The following demographic variables served as independent variables: gender. age, marital status, level of education. position in labour market and area of residence (urban versus rural).

An assessment of the internal reliability of the measuring instrument was conducted by calculating Cronbach alpha coefficients using the computer programme SAS (SAS Institute. 1990). Alphas ranged from 0.784 10 0.721 (Table 2) for individual marketing mix elements (Ps) indicating acceptable levels of internal consistency (Nunnally. 1978: Peterson. 1994). 


\begin{tabular}{|c|c|c|c|c|}
\hline & $\begin{array}{l}\text { Gaski \& Etzel } \\
\text { (1986) }\end{array}$ & $\begin{array}{l}1990 \\
\text { study }\end{array}$ & $\begin{array}{l}1993 \\
\text { study }\end{array}$ & $\begin{array}{c}\text { This study } \\
\text { (1996) }\end{array}$ \\
\hline \multicolumn{5}{|c|}{ Product index } \\
\hline & $\begin{array}{l}\text { Item-total } \\
\text { correlation }\end{array}$ & $\begin{array}{l}\text { Item-total } \\
\text { correlation }\end{array}$ & $\begin{array}{l}\text { Item-total } \\
\text { correlation }\end{array}$ & $\begin{array}{l}\text { Item-total } \\
\text { correlation }\end{array}$ \\
\hline Product 1 & 0.491 & 0.735 & 0.561 & 0.495 \\
\hline Product 2 & 0.543 & 0.726 & 0.597 & 0.521 \\
\hline Product 3 & 0.570 & 0.633 & 0.501 & 0.499 \\
\hline Producı 4 & 0.480 & 0.723 & 0.569 & 0.477 \\
\hline Product 5 & 0.642 & 0.780 & 0.599 & 0.546 \\
\hline Product 6 & 0.639 & 0.746 & 0.656 & 0.475 \\
\hline Product 7 & 0.533 & 0.701 & 0.579 & 0.542 \\
\hline Alpha & 0.817 & 0.846 & 0.832 & 0.784 \\
\hline \multicolumn{5}{|l|}{ Price index } \\
\hline Price I & 0.514 & 0.549 & 0.426 & 0.435 \\
\hline Price 2 & 0.477 & 0.542 & 0.396 & 0.407 \\
\hline Price 3 & 0.500 & 0.684 & 0.483 & 0.515 \\
\hline Price 4 & 0.403 & 0.593 & 0.309 & 0.343 \\
\hline Price 5 & 0.333 & 0.496 & 0.327 & 0.518 \\
\hline Price 6 & 0.646 & 0.723 & 0.525 & 0.580 \\
\hline Price 7 & 0.630 & 0.699 & 0.488 & 0.567 \\
\hline Alpha & 0.772 & 0.716 & 0.703 & 0.762 \\
\hline \multicolumn{5}{|c|}{ Advertising index } \\
\hline Advert ! & 0.359 & 0.549 & 0.367 & 0.375 \\
\hline Advert 2 & 0.544 & 0.687 & 0.658 & 0.518 \\
\hline Advert 3 & 0.567 & 0.697 & 0.668 & 0.495 \\
\hline Advert 4 & 0.515 & 0.730 & 0.450 & 0.430 \\
\hline Advert 5 & 0.469 & 0.690 & 0.565 & 0.497 \\
\hline Advert 6 & 0.314 & 0.592 & 0.403 & 0.346 \\
\hline Adven 7 & 0.600 & 0.731 & 0.637 & 0.543 \\
\hline Alpha & 0.761 & 0.794 & 0.801 & 0.743 \\
\hline \multicolumn{5}{|c|}{ Retailing index } \\
\hline Retail I & 0.604 & 0.723 & 0.580 & 0.602 \\
\hline Retail 2 & 0.591 & 0.691 & 0.467 & 0.476 \\
\hline Retail 3 & 0.622 & 0.769 & 0.588 & 0.552 \\
\hline Retail 4 & 0.410 & 0.446 & 0.306 & 0.278 \\
\hline Retail 5 & 0.133 & 0.308 & 0.115 & 0.070 \\
\hline Retail 6 & 0.587 & 0.729 & 0.545 & 0.527 \\
\hline Retail 7 & 0.631 & 0.733 & 0.573 & 0.571 \\
\hline Alpha & 0.783 & 0.755 & 0.742 & 0.721 \\
\hline
\end{tabular}

but some individual items returned low (lower than 0.35 ) item-to-total correlations (Retail 5 for instance).

\section{Validity results}

All 28 items were subjected to an exploratory factor analysis procedure to assess the discriminant validity of the measuring instrument. The computer programme BMDP4M (Frane, Jennrich \& Sampson, 1990) was used, specifying Maximum likelihood as the method of initial factor extraction and a Direct Quartimin oblique rotation of the original factor matrix (Jennrich \& Sampson, 1966).

\begin{tabular}{|c|c|c|c|c|}
\hline & $\begin{array}{c}\text { Factor I } \\
\text { Retail } \\
\end{array}$ & $\begin{array}{c}\text { Factor } 2 \\
\text { Price } \\
\end{array}$ & $\begin{array}{c}\text { Factor } 3 \\
\text { Advert } \\
\end{array}$ & $\begin{array}{l}\text { Factor } 4 \\
\text { Product } \\
\end{array}$ \\
\hline PRODI & 0.401 & 0.167 & -0.081 & 0.252 \\
\hline PROD2 & 0.484 & 0.157 & -0.026 & 0.205 \\
\hline PROD3 & 0.132 & 0.085 & 0.048 & 0.560 \\
\hline PROD4 & 0.055 & 0.160 & 0.043 & 0.458 \\
\hline PROD5 & 0.258 & -0.018 & 0.226 & 0.488 \\
\hline PROD6 & 0.292 & 0.086 & 0.253 & 0.291 \\
\hline PROD7 & 0.329 & 0.269 & -0.051 & 0.236 \\
\hline PRICEI & -0.026 & 0.414 & 0.074 & 0.212 \\
\hline PRICE2 & -0.197 & 0.503 & 0.117 & 0.121 \\
\hline PRICE3 & 0.282 & 0.594 & -0.075 & -0.202 \\
\hline PRICE4 & 0.168 & 0.351 & 0.047 & -0.050 \\
\hline PRICE5 & -0.040 & 0.475 & 0.257 & 0.134 \\
\hline PRICE6 & 0.217 & 0.615 & 0.025 & -0.112 \\
\hline PRICE7 & 0.190 & 0.621 & -0.055 & 0.019 \\
\hline ADVERTI & 0.389 & 0.049 & 0.416 & -0.284 \\
\hline ADVERT2 & 0.017 & -0.045 & 0.656 & 0.009 \\
\hline ADVERT3 & 0.075 & -0.014 & 0.522 & 0.177 \\
\hline ADVERT4 & -0.155 & 0.075 & 0.524 & -0.002 \\
\hline ADVERT5 & 0.288 & 0.082 & 0.549 & -0.235 \\
\hline ADVERT6 & -0.157 & 0.125 & 0.386 & 0.027 \\
\hline ADVERT7 & -0.036 & 0.047 & 0.581 & 0.269 \\
\hline RETAILI & 0.693 & 0.065 & -0.049 & 0.025 \\
\hline RETAIL2 & 0.465 & -0.100 & 0.079 & 0.252 \\
\hline RETAIL3 & 0.719 & 0.021 & -0.026 & -0.063 \\
\hline RETAIL4 & 0.350 & 0.034 & 0.066 & 0.005 \\
\hline RETAIL5 & -0.233 & 0.534 & 0.092 & 0.113 \\
\hline RETAIL6 & 0.450 & -0.004 & 0.194 & 0.290 \\
\hline RETAIL7 & 0.678 & 0.114 & -0.104 & -0.024 \\
\hline Eigen value & 3.246 & 2.393 & 2.235 & 1.547 \\
\hline
\end{tabular}

Table 3 shows that most of the 28 items loaded on separate factors as expected except for PROD1 and PROD2 which loaded on the Retail factor and RETAIL5 which loaded on the price factor. The exploratory factor analysis results thus suggest a reasonable degree of discriminant validity.

\section{Empirical results}

Table 4 shows that the overall marketing index is positive for the first time in three time periods (1990; 1993 and 1996). The marketing index is positive largely because of the relatively large (positive) retailing index and the positive price index, while the two negative indices (product and advertising) are only marginally negative.

The indices seem to differ somewhat from the findings of Barksdale et al. (1982: 85) who, in a study encompassing six countries, reported fairly positive perceptions of the availability of products (distribution, retailing) but their respondents expressed concern about product quality and the high prices of products and services. A possible explanation for this somewhat surprising finding that price returned a relatively large positive index is a period of relative price stability in 
Table 4 Indices: marketing index and marketing instruments

\begin{tabular}{lccc}
\hline Marketing instrument & 1990 study & 1993 study & Index' (1996) \\
\hline Product & -2.72 & -9.94 & -5.40 \\
Price & -8.47 & -24.37 & +13.11 \\
Advertising & -6.43 & +0.61 & -1.33 \\
Retailing & +1.36 & -0.42 & +22.91 \\
\hline Marketing index & -16.26 & -34.13 & +29.28 \\
\hline I. Range: -70.00 to +70.00 & & \\
2. Range: -280.00 to +280.00 & & \\
\hline
\end{tabular}

South Africa coupled with developments such as lower new motor vehicle prices, stable agricultural prices due to improved weather conditions and increasing competition at retail level as more and more international companies enter the South African market. The negative attitudes towards advertising reported by Barksdale et al. (1982) in all six countries studied are confirmed, to some extent, in this study (advertising index - 1.33). It must be pointed out, however, that the advertising index has never moved much beyond the zero mid-point in any of the three studies (Table 4) and the 1996 results coincide with a period when complaints to the Advertising Standards Authority have declined by $28 \%$ compared to 1995 (Koenderman, 1996: 98-99).

\section{Influence of demographic variables on the marketing index ${ }^{2}$}

To evaluate the influence the demographic variables (gender, age, level of education [EDUC], and area of residence [AREA]) exert on the dependent variables (the marketing index and the four Ps), five regression analyses were conducted. The PROC GLM procedure available on the computer package SAS (SAS Institute, 1990) was used for this purpose

Table 5 shows that there is a negative relationship between level of education and the overall marketing index. In other words, the better educated the respondents the more negative is their attitude towards marketing and marketing practices. According to Table 5 English-speaking respondents are also considerably more critical of marketing and marketing practices than Afrikaans-speaking respondents and those whose home language is an African language. Table 5 also shows that there is no relationship between attitudes towards

\begin{tabular}{|c|c|c|c|}
\hline \multicolumn{4}{|c|}{ Dependent variable: Marketing index } \\
\hline & Coefficient & $T$ value & $p>t$ \\
\hline Intercept & 51.10 & 3.60 & 0.0003 \\
\hline Education & -5.69 & -2.08 & $0.0380^{*}$ \\
\hline African language & 28.03 & 2.59 & $0.0100^{*}$ \\
\hline English language & -24.87 & -1.74 & 0.0831 \\
\hline \multicolumn{4}{|l|}{${ }^{*}=\mathrm{p}<0.05$} \\
\hline \multicolumn{4}{|l|}{${ }^{* *}=p<0.01$} \\
\hline $\mathbf{R}^{2}=3.1 \%$ & & & \\
\hline
\end{tabular}

marketing and the respondent's gender, age and area of residence (rural versus urban).

In the 1990 study only one demographic variable influenced the marketing index. Older respondents were particularly critical of marketing at the time. In the 1993 study (as is the case in the present study) a negative relationship towards marketing and marketing practices among well-educated respondents emerged. In the 1993 study Afrikaans-speaking respondents also revealed a particularly negative attitude towards the marketing fraternity.

\section{Influence of demographic variables on the product index}

As was the case with the 1990 study, English-speaking respondents reported a particularly negative attitude towards products and product quality during this study (Table 6). In addition, the 1990 study revealed that females hold a more negative attitude towards product-related issues than males. In the 1993 study English-speakers also expressed the same negative sentiments about products as did relatively welleducated respondents.

\section{Influence of demographic variables on the price index}

Table 7 shows that there is a relationship between the price index and gender, level of education and language. Female respondents, those who are relatively better qualified academically and English-speaking respondents are significantly more negative about pricing and pricing practices than males, less well-qualified respondents and those whose home language is either Afrikaans or an African language.

In the 1993 study female respondents were also very negative about pricing but, unlike the present study, Afrikaansspeaking respondents then reported particularly negative attitudes towards pricing. In the 1990 study urban respondents reported that they were more dissatisfied with pricing than their counterparts who live in rural areas.

By implication, Table 7 shows that there is no relationship between age and area of residence and the price index.

\section{Influence of demographic variables on the advertising} index

Age and area of residence are the only demographic variables that exert a significant impact on the adverusing index. The relationship between advertising and age is negative: the older respondents are, the more negatively do they view advertising. Respondents who live in rural areas also report more negative attitudes towards advertising than their

\begin{tabular}{|c|c|c|c|}
\hline \multicolumn{4}{|c|}{ Dependent variable: Product index } \\
\hline & Coefficient & $T$ value & $p>t$ \\
\hline Intercept & -5.81 & -1.00 & 0.3189 \\
\hline African language & 11.69 & 2.63 & $0.0089 * *$ \\
\hline English language & -11.72 & -1.99 & $0.0469^{*}$ \\
\hline \multicolumn{4}{|l|}{$* p<0.05$} \\
\hline \multicolumn{4}{|l|}{$* *=p<0.01$} \\
\hline$R^{2}=2.5 \%$ & & & \\
\hline
\end{tabular}




\begin{tabular}{|c|c|c|c|}
\hline \multicolumn{4}{|c|}{ Dependent variable: Price index } \\
\hline & Coefficient & $T$ value & $p>t$ \\
\hline Intercept & 18.66 & 4.65 & 0.0001 \\
\hline Gender & 1.97 & 2.29 & $0.0225^{*}$ \\
\hline Education & -1.53 & -1.98 & $0.0485^{*}$ \\
\hline African language & 10.18 & 3.32 & $0.0010^{* *}$ \\
\hline English language & -11.48 & -2.83 & $0.0048^{* *}$ \\
\hline \multicolumn{4}{|l|}{$*=p<0.05$} \\
\hline \multicolumn{4}{|l|}{$* *=p<0.01$} \\
\hline $\mathrm{R}^{2}=4.2 \%$ & & & \\
\hline
\end{tabular}

\begin{tabular}{|c|c|c|c|}
\hline \multicolumn{4}{|c|}{ Dependent variable: Advertising index } \\
\hline & Coefficient & $T$ value & $p>t$ \\
\hline Intercept & 5.02 & 1.29 & 0.1986 \\
\hline Age & -1.89 & -3.24 & $0.0013^{* *}$ \\
\hline Area & 2.30 & 2.01 & $0.0448 *$ \\
\hline \multicolumn{4}{|c|}{$*=p<0.05$} \\
\hline \multicolumn{4}{|c|}{$* *=p<0.01$} \\
\hline$R^{2}=3.4 \%$ & & & \\
\hline
\end{tabular}

counterparts who live in urban areas. By implication, Table 8 shows that there is no relationship between gender, level of education, home language and the advertising index.

\section{Influence of demographic variables on the retailing index}

Level of education is the only demographic variable which exerts any influence on the retailing index. The relationship is again negative. In other words, respondents who are relatively well qualified are significantly more negative ( $\mathrm{p}<$ 0.01 ) about retailing and retailing service.than those who are not so well qualified in academic terms. This finding concurs with the results of the 1993 study. In the 1990 study none of the demographic variables influenced the retailing index.

The results also mean that there is no relationship between how South African consumers perceive the availability of products, retail services and retailing in general and their gender, age and area of residence (rural versus urban). This finding was somewhat surprising in one respect. It was expected

Table 9 Influence of demographic variables on the retailing index

\begin{tabular}{lccc}
\hline \multicolumn{3}{l}{ Dependent variable: Retailing index } \\
\hline & Coefficient & T value & $\mathrm{p}>\mathrm{t}$ \\
\hline Intercept & 33.23 & 6.63 & 0.0001 \\
Education & -3.46 & -3.58 & $0.0004^{* *}$ \\
\hline$* *=p<0.01$ & & & \\
$\mathrm{R}^{2}=5.2 \%$ & & \\
\hline
\end{tabular}

that rural consumers would rate the level of service they receive from the smaller outlets typical of rural areas more favourably than those living in larger urban areas.

\section{Summary and conclusions}

The South African marketing fraternity can take some comfort from the results reported in this study. The overall marketing index is positive for the first time since this project was initiated. It appears as if the rather critical views alluded to earlier are not universally held.

Considering the improvement of the price index from -24.37 in 1993 to +13.11 , it appears as if retail managers in particular have managed to influence consumer attitudes towards pricing more effectively. In other words, retailers may have been successful in containing price increases or have succeeded in justifying price increases to the public. This was probably aided by a macro-economic environment in which inflation has been reduced and an era of relative price stability. The (relatively speaking) high positive retailing index also suggests that retailers in particular have succeeded - at least to some extent in improving service levels. If that is the case it may suggest that managers are more aware of the service needs of customers. To this end the research efforts of pioneers in the field of service marketing such as Parasuraman, Zeithaml \& Berry (1988) and Grönroos (1980) and others may be bearing fruit at retail level.

The product index has been stable but negative in all three time periods. In other words, consumers are not satisfied with the need satisfaction performance of products and product quality in particular. The believe that it happens too often that products are defective in some way and that in general, product quality has declined over the years.

The advertising index has also been disappointing over all three time periods. It is clear that the advertising profession has an image problem in that the role of advertising in a modern economy is not properly understood or appreciated. Older and rural consumers, in particular, are more likely to think that advertising is false and deceitful rather than informative. These characteristics could suggest that efforts to improve the image of the profession should incorporate market segments that could be described as conservative. Alternatively, advertising to these audiences should be carefully considered. As pointed out earlier, though, complaints to the Advertising Standards Authority have declined in recent times, suggesting at least some improvement.

Despite the first ever positive marketing index the profession cannot however, rest on its laurels. Care should be taken to nurture the current positive attitude towards marketing and marketing practices.

\section{Future research}

As suggested by Gaski \& Etzel (1986: 72), a number of advantages will stem from measuring consumer sentiment towards marketing including sensitizing marketers to the importance of consumer perceptions and enhancing the image of the profession in public eyes. The true value of such a study, however, is enhanced if repeated regularly. In this way, trends can be identified which will ensure that corrective action (if required) is focussed on the most needed areas. Certainly in the era of interactive marketing data will be 
much easier to obtain and, with the co-operation of consumers, attitudes can be regularly measured. Such information and research could lead to an enhanced view of marketing by most consumers if such knowledge is applied ethically and effectively.

As the regression analyses reported in this study again returned relatively low $R^{2}$ values, future studies should consider the use of alternative independent variables to explain the variance in the various indices such as lifestyles and macroeconomic variables.

As this study is the third in what has turned out to be a longitudinal study that is repeated regularly over time, it will be possible to assess consumer sentiment towards marketing in a changing environment.

\section{Notes}

1. Letters column, Otago Daily Times, 2 November 1996: 8.

2. Only the independent variables that exert a significant influence on the dependent variable are reported in Tables 5 to 9.

\section{Acknowledgement}

The financial assistance of the Centre for Science Development towards this research project is hereby acknowledged. Opinions expressed and conclusions reached are those of the authors and should not be attributed to the Centre for Science Development.

\section{References}

Anderson, E.W., Fornel, C. \& Lehman, D.R. 1994. Customer satisfaction, market share and profitability: findings from Sweden, Journal of Marketing, 58(1): 53-66.

Barksdale, H.C., Darden, W.R. \& Perreault, W.D. 1976. Changes in consumer attitudes toward marketing, consumerism, and government regulation: 1971-1975, Journal of Consumer Affairs, 10: 117-139.

Barksdale, H.C., Perreault, W.D., Arndt, J., Barnhill, J.A., French, W.A., Halliday, M. \& Zif, J. 1982. A cross-national survey of consumer attitudes towards marketing practices, consumerism and government regulations, Columbia Journal of World Business, Summer: $71-86$.
Boshoff, C. \& Du Plessis, A.P. 1990. How is marketing doing? A descriptive analysis of consumer sentiment data, Proceedings of the Annual Conference of the South African Institute of Management Scientists. Pretoria, November: 142-164.

Boshoff, C. \& Du Plessis, A.P. 1992. South African consumer sentiment towards marketing, South African Journal of Business Management, 23(2): 33-39.

Boshoff, C. \& Du Plessis, A.P. 1995. Revisiting the South African marketing index, South African Joumal of Business Management, 26(2): 49-57.

Fornel, C., Johnson, M.D., Anderson, E.W., Cha, J. \& Bryant, E. 1996. The American customer satisfaction index; nature, purpose and findings, Journal of Marketing, 60(4): 7-18.

Frane, J., Jennrich, R.I. \& Sampson, P.F. 1990. P4Mfactor analysis. In Dixon, W.J. \& Brown, M.B. Eds. BMDP statistical software: Vol. 1, Berkeley, C.A.: University of California: 311-337.

Gaski J.F. \& Etzel, M.J. 1986. The index of consumer sentiment toward marketing, Journal of Marketing, 50: 71-81.

Grönroos, C. 1990. Service management and marketing. Lexington, Massachusetts: Lexington Books.

Jennrich, R.I. \& Sampson, P.F. 1966. Rotation for simple loadings, Psychometrica, 31(3): 313-323.

Koenderman, T. 1996. Fewer complaints about ads. Financial Mail, 144(1): 98-99.

Kohli, A.K. \& Jaworski, B.J. 1990. Market orientation: the construct, research propositions and mangerial implications, Journal of Marketing, 54 (2): 1-18.

Naver, J.C. \& Slater, S.F. 1990. The effect of a market orientation on business profitability, Journal of Marketing, 54(4): 20-35.

Neese, W.T. 1996. Marketing concept evangelism, Academy of Marketing Science News, 17(2): 6.

Nunnally, J. 1978. Psychometric theory. 2nd Edition. New York: McGraw-Hill.

Parasuraman, A., Zeithaml, V.A. \& Berry, L.L. 1988. SERVQUAL: a multi-item scale to for measuring perceptions of servive quality, Journal of Retailing, Spring: 12-40.

Peterson, R.A. 1994. A meta-analysis of Cronbach's alpha, Journal of Consumer Research, 21(2): 381-391.

SAS Institute, Inc. 1988. SAS/STAT. User's guide. Release 6.03. Cary, N.C. 